\title{
Application of coal ash to environmental improvement Transformation into zeolite, potassium fertilizer, and FGD absorbent
}

Kikuchi, R.

Elsevier Science B.V.

1999

Kikuchi, R. 1999. Application of coal ash to environmental improvement Transformation into

pÿzeolite, potassium fertilizer, and FGD absorbent. Resources, Conservation and Recycling 27333346.

http://hdl.handle.net/1975/211

Downloaded from Helda, University of Helsinki institutional repository.

This is an electronic reprint of the original article.

This reprint may differ from the original in pagination and typographic detail.

Please cite the original version. 


\title{
Application of coal ash to environmental improvement Transformation into zeolite, potassium fertilizer, and FGD absorbent
}

\author{
Ryunosuke Kikuchi * \\ Department of Environmental Protection, B-bldg., No.128, Faculty of Agriculture and Forestry, \\ P.O.Box 27 (Viikki), 00014 University of Helsinki, Helsinki, Finland
}

Received 5 March 1999; received in revised form 1 June 1999; accepted 3 June 1999

\begin{abstract}
The rapid increase in population and economic growth have led to an increase in energy demand. Coal reserves are distributed worldwide, and coal is now known to be the most stable and available energy source. However, utilization of coal as an energy source involves the generation of a great amount of coal ash, and the recycling rate of the ash is rather low. Coal ash is mainly used in civil construction materials, and there is a limit to the demand for coal ash by construction industries: therefore, the increasing amount of coal ash will be a serious problem in the near future. Different applications should be considered. In this paper, three environmentally-friendly methods for coal ash recycling are described. Firstly, alkali treatment can transform coal ash to zeolite, which is used in deodorant and for wastewater treatment and soil improvement. Secondly, potassium silicate fertilizer is produced from coal ash and has a higher retentivity in the soil than that of conventional fertilizers. Thirdly, emission of sulfur dioxide is controlled by flue gas desulfurization using coal ash. It is considered that environmentally-friendly use of coal ash is important from the viewpoints of energy, economy, and environmental strategy in order to realize the concept of sustainable development. (C) 1999 Elsevier Science B.V. All rights reserved.
\end{abstract}

Keywords: Coal; Fly ash; Recycling; Power plant; Zeolite; Fertilizer; Desulfurization

* Corresponding author. Tel.: + 358-9-708-58539; fax: + 358-9-708 58462.

0921-3449/99/\$ - see front matter (C) 1999 Elsevier Science B.V. All rights reserved.

PII: S0921-3449(99)00030-0 


\section{Introduction}

Energy consumption has been increasing during this century with the increase in global pollution. For example, global primary energy consumption has increased from 2500 Mtoe (million tons of oil equivalent) in 1971 to 3500 Mtoe in 1996 [1]. Coal accounts for around $25 \%$ of total global primary energy [1]. In other words, coal is an important energy resource and coal reserves are widely distributed. However, some solid wastes such as fly ash and bottom ash are discharged in large quantities by firing coal to obtain energy. The global amount of coal ash emitted from thermal power plants is over 500 million tons per year, and the global recycling rate of coal ash is about 15\% [2]. The present recycling rate of these solids is not so high, so most are deposited in landfills and/or coal mines. Therefore, there is a possibility that these solid wastes will cause environmental problems. It is considered that the recycling of such solid wastes makes it possible to save mineral resources and realize environmentally-friendly utilization of energy. Coal ash recycling is discussed from the following viewpoints in this paper:

- Transformation of coal ash into zeolite

- Transformation of coal ash into potassium fertilizer

- Transformation of coal ash into desulfurizing agent

\section{Potential problems in the use of coal ash}

The ash separated in the combustion process can be used for conventional purposes, namely, mixed with cement and concrete. However, the production amount of the cement and concrete industries, which are the main users of coal ash today, remains unchanged; therefore, the disposal of the increased amount of coal ash will become a serious problem [3]. Construction work that demands coal ash as a raw material and the amount of coal ash emissions at thermal power stations depend on the season. Fig. 1 shows that a great amount of solid wastes such as fly ash and bottom ash is emitted in the winter season [Bulgarian Ministry of the Environment, unpublished data (1996)].

Fly ash and bottom ash are emitted in the winter months while thermal power stations are operating at full capacity. On the other hand, the construction industry needs most of the coal ash during the building season in the summer [4]. The distance between the construction sites and the power stations is another factor emphasizing the importance of interim storage facilities. The recycling rate of coal ash was 23\% in the USA, 42\% in the European Union, and 46\% in Japan in 1994 [5], and it follows from Fig. 2 that most coal fly ash is used for cement and construction materials [6].

Over the last few years, the cement industry has reduced its use of ash because other materials have replaced ash as a cement additive [4]. The demand for coal ash in the construction and cement industries is limited. Moreover, the seasonal problem and the problem of location affect the rate of coal ash recycling. Because the global disposal amount of coal ash will increase with an increase in energy 


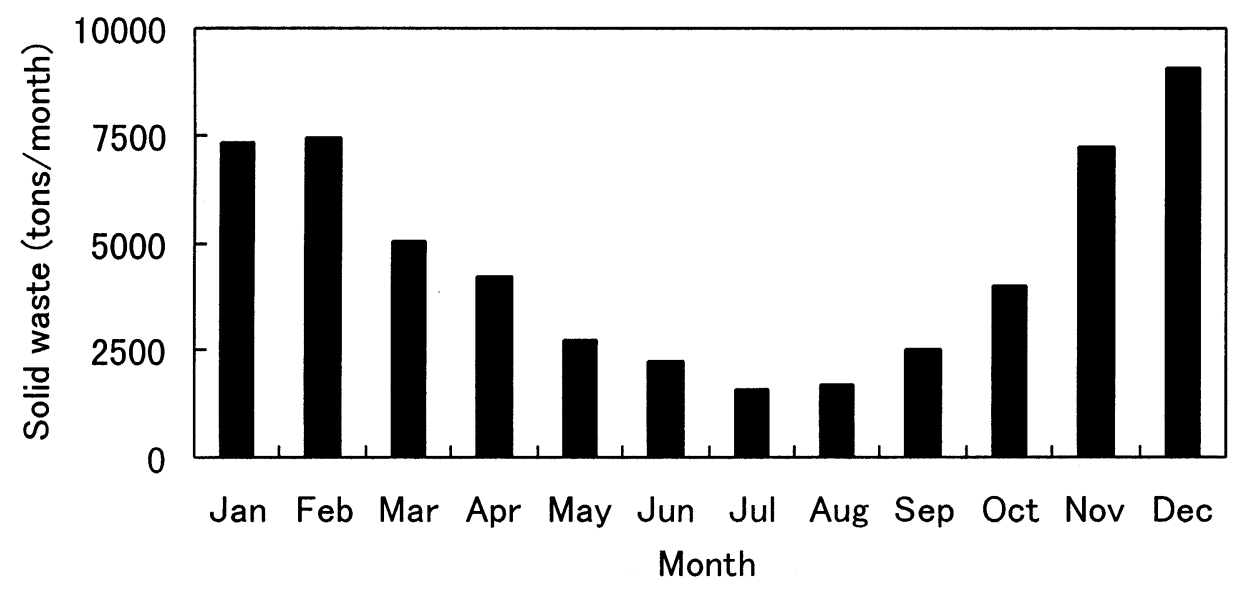

Fig. 1. Monthly amount of solid waste at Russe coal-fired power station (1994). Capacity: 400 MW, Fuel type: coal, Commissioning year: 1964 and 1984, Output in 1994: $638 \times 10^{6} \mathrm{kWh}$ of electricity and $377 \times 10^{3}$ Gcal of heat.

demand, it is now necessary to consider coal ash applications other than the present ones; therefore, some new applications are introduced in this paper.

\section{Zeolitization}

The principle elements of coal ash are $\mathrm{SiO}_{2}(40-65 \mathrm{wt} \%)$ and $\mathrm{Al}_{2} \mathrm{O}_{3}(25-40 \mathrm{wt} \%)$, with the proportion of such contents depending on the properties of the coal [7]. In addition, small quantities of $\mathrm{Fe}_{2} \mathrm{O}_{3}, \mathrm{Mg}, \mathrm{Ca}, \mathrm{P}$, and Ti are contained in coal ash [7]. Coal ash can be considered to be an aluminum silicate compound containing some impurities. The properties of volcanic ash are similar to those of aluminosilicate, and it is known that volcanic ash is alkalized to zeolite [8], which is used as a drying agent, deodorant [9], freshness-holding agent, water-softening agent, soil conditioner, fertilizer additive, and feed additive. Moreover, zeolite has a molecular sieve

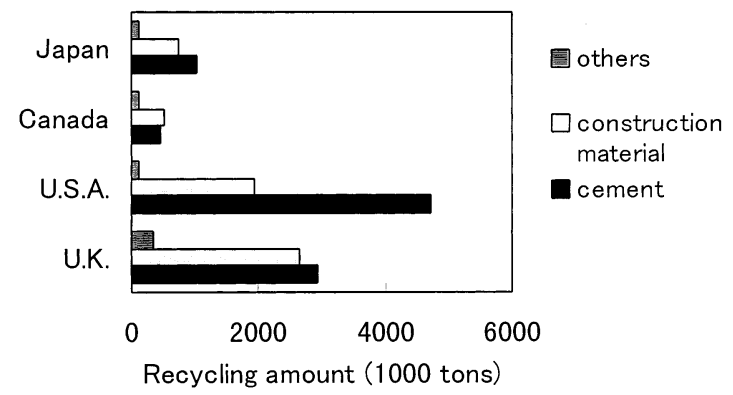

Fig. 2. Amount of used coal fly ash by application (1986). 
Table 1

Chemical composition of coal ash

\begin{tabular}{lcl}
\hline Composition & wt $\%$ & Analytical method \\
\hline $\mathrm{SiO}_{2}$ & 54.0 & gravimetric analysis \\
$\mathrm{Al}_{2} \mathrm{O}_{3}$ & 28.0 & EDTA titration \\
$\mathrm{Fe}_{2} \mathrm{O}_{3}$ & 8.30 & dichrometry \\
$\mathrm{CaO}$ & 3.0 & EDTA titration \\
$\mathrm{MgO}$ & 1.60 & EDTA indirect titration \\
$\mathrm{TiO}_{2}$ & 1.64 & absorptiometry with $\mathrm{HCl}$ solution \\
$\mathrm{SO}_{3}$ & 1.20 & gravimetric analysis \\
$\mathrm{Na}_{2} \mathrm{O}$ & 0.31 & atomic absorption spectrometry \\
$\mathrm{K}_{2} \mathrm{O}$ & 1.33 & atomic absorption spectrometry \\
\hline
\end{tabular}

function which can be used for the selective removal of pollutants, and the process for molecular sieve adsorption of $\mathrm{NO} x, \mathrm{SO} x$ and $\mathrm{Hg}$ has been commercialized $[10,11]$. Nowadays, the common explanation of the zeolitization mechanism is that alkali treatment converts aluminosilicate compounds such as coal ash mainly into philipsite $\left(\mathrm{Na}_{2} \mathrm{O}^{*} \mathrm{Al}_{2} \mathrm{O}_{3}{ }^{*} 3.3-5.3 \mathrm{SiO}_{2}{ }^{\circ} n \mathrm{H}_{2} \mathrm{O}\right)$ and to a lesser extent into hydroxy-sodalite and mordenite-like minerals. These formed minerals are classed mineralogically as zeolite whose structure is a three-dimensional network of $\mathrm{SiO}_{4}$ and $\mathrm{AlO}_{4}$ tetrahedra linked together by the sharing of all the oxygen atoms [12]. The zeolitization of coal ash on a semi-industrial scale was conducted on the basis of this previous research, and the technical results and economic considerations are reported in this part.

\subsection{Material}

Fly ash as a raw material for zeolitization was supplied by burning Australian coal at the incineration plant. A component analysis of the fly ash was conducted, and the results are summarized in Table 1.

\subsection{Process flow}

Boiling 1.5 tons $/ \mathrm{h}$ of coal ash with $0.3 \mathrm{~m}^{3} / \mathrm{h}$ of $48 \%$ caustic soda aqueous solution produces 1.2 tons $/ \mathrm{h}$ of zeolite. A simplified process flow is illustrated in Fig. 3.

The process for this zeolitization plant is summarized as follows: fly ash to be treated is fed from a jet pack car and stored in an ash hopper. The stored ash is supplied to a reactor together with the caustic soda solution whose concentration and temperature are previously adjusted to $48 \%$ (e.g. $2 \mathrm{~N}$ ) and $95-105^{\circ} \mathrm{C}$ respectively. The ash is stirred and boiled at around $100^{\circ} \mathrm{C}$ in the reactor until it is transformed into zeolite in a $5 \mathrm{~h}$ batch-type operation. After completion of the reaction, continuous operations are carried out. The mixture is transferred from the reactor to a buffer tank, and then the caustic soda solution contained in the mixture is removed from the synthesized zeolite in a liquid separator. The separated caustic 
soda solution is returned to the caustic soda tank, and the zeolite is washed with water in a washer to remove the remaining caustic soda. The washed zeolite is dehydrated in a dewaterer and dried in a dryer, and is then temporarily stored in a product hopper. The stored zeolite is granulated depending on the specifications of each application and is then packaged. The alkaline waste liquid emitted from the above-mentioned process is treated with diluted $\mathrm{HCl}$ solution $(38 \%)$ in a waste equalization tank for the purpose of neutralizing it.

\subsection{Optimal conditions}

As mentioned above, the structure of zeolite consists of a three-dimensional network of $\mathrm{SiO}_{4}$ and $\mathrm{AlO}_{4}$. Because the negative charge is constantly generated by an electrical imbalance among the aluminum atom and four oxygen atoms in the $\mathrm{SiO}_{4}$, zeolite generally has a high cation exchange capacity (CEC), which indicates how many cation ions can be ion-exchanged. The CEC is an important indicator for evaluating the quality of zeolite, and zeolite's high exchangeability makes it suitable for use in wastewater treatment, fertilizer additive, feed additive, and so on. The following parameters are selected to find out how to increase the CEC value of the zeolitized ash efficiently: reaction temperature, reaction time, and concentration of caustic soda aquatic solution. CEC values were obtained by measuring the concentration of $\mathrm{Ca}^{2+}$ in an extracted solution of $\mathrm{CaCl}_{2} / \mathrm{Ca}\left(\mathrm{CH}_{3} \mathrm{COO}\right)_{2}$ by use of atomic absorption spectrometry [13], and the measured CEC values are expressed in units of meq (milligram equivalent) $/ 100 \mathrm{~g}$. The results obtained by this semi-industrial experiment in the manner described above are shown in Fig. 4.

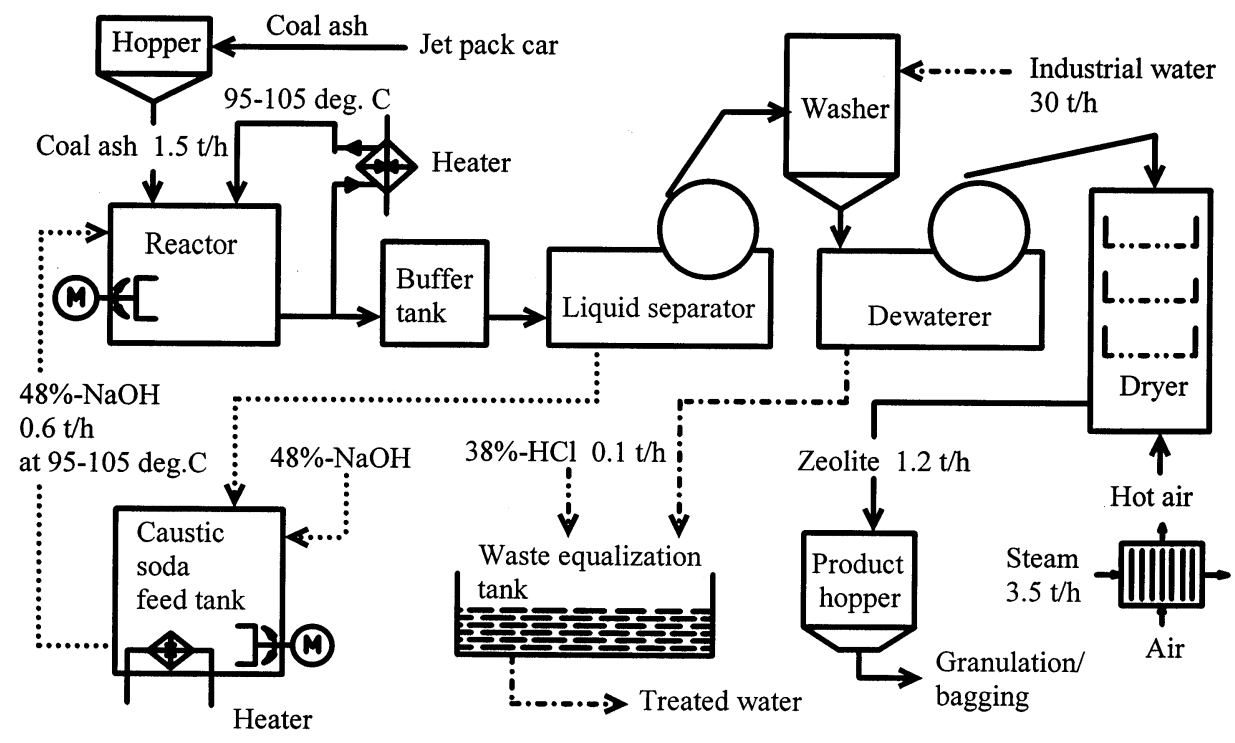

Fig. 3. Process flow of zeolitization plant (1.5 tons/hour). 


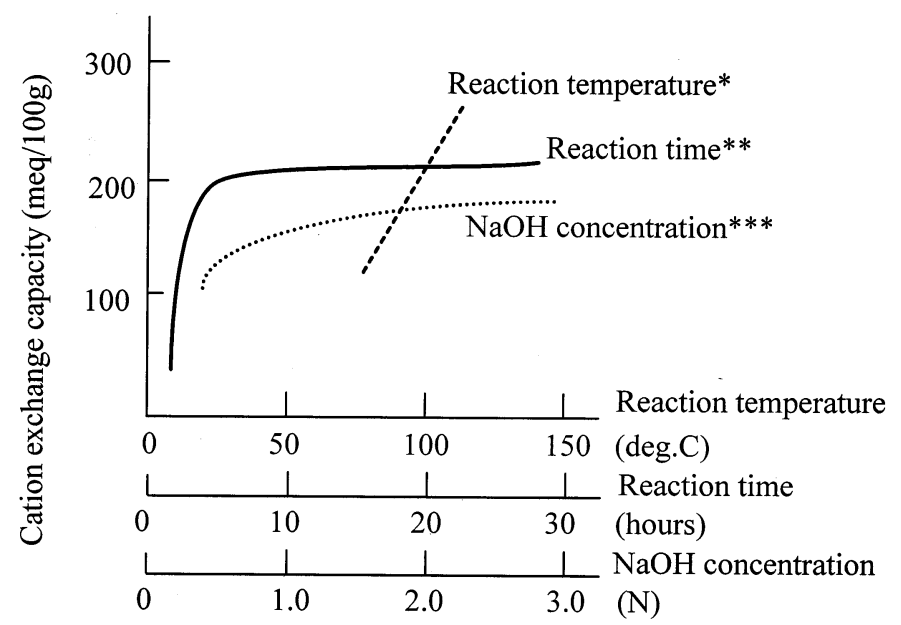

Fig. 4. Effects of reaction temperature, reaction time, and caustic soda $(\mathrm{NaOH})$ concentration on cation exchange capacity of the formed zeolite. ${ }^{*}$ Reaction time $=5 \mathrm{~h}, \mathrm{NaOH}$ concentration $=2 \mathrm{~N}$; $* *$ Reaction temperature $=100^{\circ} \mathrm{C}, \mathrm{NaOH}$ concentration $=2 \mathrm{~N} ; * * *$ Reaction temperature $=100^{\circ} \mathrm{C}, \mathrm{NaOH}$ concentration $=2 \mathrm{~N}$.

As is seen in Fig. 4, the CEC value of the formed zeolite is affected by the reaction temperature, reaction time, and $\mathrm{NaOH}$ concentration. The reaction temperature and reaction time are especially important factors in the zeolitization process. Because the CEC value of the obtained zeolite varies in correlation with the reaction temperature, this can be expressed simply as:

$\mathrm{CEC}(\mathrm{meq} / 100 \mathrm{~g})=6.2 \times$ Reaction temperature $\left({ }^{\circ} \mathrm{C}\right)-415$

That is, there is a strong relation between the CEC of the formed zeolite and the reaction temperature. It is not advisable to treat coal ash at an extremely high temperature to obtain a high CEC because a high-temperature operation consumes considerable energy and affects the reactor life. For this reason, a temperature range of $95-105^{\circ} \mathrm{C}$ is applied. Regarding the relation of the CEC with the reaction time, the CEC value increases greatly within the first $5 \mathrm{~h}$ and then shows little increase. A $5 \mathrm{~h}$ reaction can be considered optimal from the economic point of view. The CEC reaches its maximum value when the concentration of caustic soda is $2.0 \mathrm{~N}$, and the value is almost constant over $2.0 \mathrm{~N}$. The optimal conditions are summarized as a temperature range during reaction of $95-105^{\circ} \mathrm{C}$, a $5 \mathrm{~h}$ reaction, and a caustic soda concentration of $2.0 \mathrm{~N}$.

\subsection{Results and economic evaluation}

Zeolite with the following properties was converted from coal ash under the above mentioned conditions: an average diameter of $10 \mu \mathrm{m}$ (sedimentography) [14], a true specific gravity of 2.6 , and a CEC of $205 \mathrm{meq} / 100 \mathrm{~g}$. A leaching test was conducted on the obtained zeolite under the following conditions to confirm its safe 
Table 2

Leaching test of zeolite

\begin{tabular}{|c|c|c|c|}
\hline Item & Result & Detection limit & Method \\
\hline alkyl mercury & not detected & $<0.0005 \mathrm{mg} / 1$ & atomic absorption \\
\hline mercury or its compounds & not detected & $<0.0005 \mathrm{mg} / 1$ & atomic absorption \\
\hline cadmium or its compounds & not detected & $<0.0005 \mathrm{mg} / 1$ & absorptiometry \\
\hline lead or its compounds & not detected & $<0.0005 \mathrm{mg} / 1$ & atomic absorption \\
\hline organic phosphides & not detected & $<0.001 \mathrm{mg} / 1$ & color test \\
\hline hexavalent chromium & not detected & $<0.0005 \mathrm{mg} / 1$ & atomic absorption \\
\hline arsenic or its compounds & not detected & $<0.001 \mathrm{mg} / 1$ & absorptiometry \\
\hline cyanides & not detected & $<0.001 \mathrm{mg} / 1$ & absorptiometry \\
\hline polychlorinated biphenyl & not detected & $<0.0005 \mathrm{mg} / 1$ & gas chromatography \\
\hline
\end{tabular}

use: leaching time of $6 \mathrm{~h}$, sample concentration of $10 \mathrm{wt} \%$, and water with $\mathrm{pH}$ $5.8-6.3$ as the solvent. The test results are summarized in Table 2.

It follows from Table 2 that the obtained zeolite is suitable for practical use without pollutants such as heavy metal being leached into the environment. Moreover, the wastewater from the process was analyzed, and the result is summarized as follows: $\mathrm{pH}$ of 7.4 measured by glass electrode method, COD of 5.1 ppm derived from measuring the consumption of permanganic acid at $20^{\circ} \mathrm{C}$, suspended solids of $6.0 \mathrm{ppm}$ measured by glass filtration, and extractive substance in $n$-hexane of $0.5 \mathrm{ppm}$ measured by infrared spectrometry using extraction with $\mathrm{CCl}_{4}$ solution [the stated testing methods are based on JIS K-0102]. This wastewater is neutralized in an equalization tank and is then discharged from the process through a thickener. As is evident from the above analytical result, the wastewater is effectively treated and does not cause secondary pollution. Next, the economic evaluation of the obtained zeolite is discussed. The CEC of natural zeolite is said to be approximately less than $150 \mathrm{meq} / 100 \mathrm{~g}$ [15]. A comparison with the CEC value of natural zeolite shows that the quality of the obtained zeolite is better than that of natural zeolite. The zeolitization of other coals was conducted under the above-mentioned optimal operating conditions in order to confirm the process performance, and the properties of the used coal and the CEC value of the obtained zeolite are shown in Table 3.

Table 3

Relation between type of coal ash and CEC value of obtained zeolite

\begin{tabular}{llllllll}
\hline Type of fly ash & \multicolumn{2}{l}{ Composition of obtained zeolite } & \multicolumn{2}{c}{ CEC } \\
\cline { 2 - 6 } (name of coal mine) & $\mathrm{T}-\mathrm{Fe}$ & $\mathrm{SiO}_{2}$ & $\mathrm{Al}_{2} \mathrm{O}_{3}$ & $\mathrm{CaO}$ & $\mathrm{Na}_{2} \mathrm{O}$ & $\mathrm{K}_{2} \mathrm{O}$ & \\
\hline Mola coal & 4.0 & 41.3 & 23.6 & 2.8 & 4.5 & 1.0 & 190 \\
Ganeda coal & 2.3 & 53.5 & 36.3 & 2.0 & 4.2 & 1.0 & 180 \\
Warara coal & 4.4 & 54.0 & 18.7 & 5.0 & 4.9 & 1.0 & 181 \\
Ikejima coal & 4.5 & 38.3 & 18.8 & 1.8 & 7.1 & 0.6 & 213 \\
\hline
\end{tabular}


It is clear that the CEC value depends on the properties of the coal ash, but zeolitization efficiencies of $180 \mathrm{meq} / 100 \mathrm{~g}$ or more were obtained with the coal ash used in the experiment by this process under the proposed optimal conditions. The same process and operating conditions might be applied to different types of coal ash. There are three main mining areas of natural zeolite in Europe: the Balkan peninsular region including Kurdjali (Bulgaria) and Zaloska Gorica (Yugoslavia); the northwestern part of Napoli (Italy) and Botzingen (Germany). There are also three mines in the USA: Mud Hills (California); Ash Meadow (Nevada) and Bowie (Arizona) [16]. There is only one mining area of natural zeolite in South America: the Yucatan peninsula [16]. Zeolite is not widely distributed but is localized in certain regions of the world. The market price of zeolite depends on its quality (grade) and cannot be generalized. It is estimated that the price of commercialized zeolite is approximately US\$ 200 to 400/ton [the Zeolite Industry Association, private communication]. From the viewpoints of quality (CEC), localization of natural zeolite mines, and comparatively high commercial price, it can be considered that the zeolite converted from coal ash may have good international marketability.

\section{Potassium silicate fertilizer}

As described in this paper, the silicate content of coal ash is around $50 \mathrm{wt} \%$. Because the silicates in coal ash are mainly vitreous and partly combine with alumina to form the crystal structure of mullite, they cannot be directly absorbed by crops [17].

Silicate reacts with magnesia and caustic potash at a sintering temperature of $900^{\circ} \mathrm{C}$ to form a chemical complex, and crops can easily absorb the nutritional elements such as silicate, potash and magnesia contained in this complex. The main reaction is expressed as follows [18]:

$$
\begin{aligned}
& \mathrm{SiO}_{2}+3 \mathrm{Al}_{2} \mathrm{O}_{3} \cdot 2 \mathrm{SiO}_{2}+2 \mathrm{KOH}+\mathrm{Mg}(\mathrm{OH})_{2} \\
& \rightarrow \mathrm{K}_{2} \mathrm{O}^{\bullet} \mathrm{Al}_{2} \mathrm{O}_{3} \cdot 2 \mathrm{SiO}_{2}+\mathrm{K}_{2} \mathrm{O}^{\bullet} \mathrm{MgO}^{\bullet} \mathrm{SiO}_{2}+2 \mathrm{H}_{2} \mathrm{O}
\end{aligned}
$$

Potassium silicate fertilizer produced from coal ash is not soluble in water but soluble in $2 \%$ citric acid solution, so that the fertilizer attaches to the soil particles, remaining in the root zone until needed by the crop, not leaching into the ground water. If the fertilizer remains in the soil, soil acidification does not take place because the fertilizer is alkaline. Fig. 5 shows absorption amounts by crop, remaining amounts in the soil and leaching amounts for this fertilizer (potassium silicate), potassium chloride and potassium sulfate [17].

Potassium silicate fertilizer increases silicified cells, sugar content, and amino acids in the crop body so that the crop has strong resistance to insects and disease and improved quality in terms of taste, shape and color $[18,19]$. Moreover, fertilizer produced from coal ash contains calcium, magnesium and iron. the latter two of which are a secondary nutrient and micronutrient, respectively to crops. As the body (especially the root) reinforced by silicate nutrition has a high lodging 


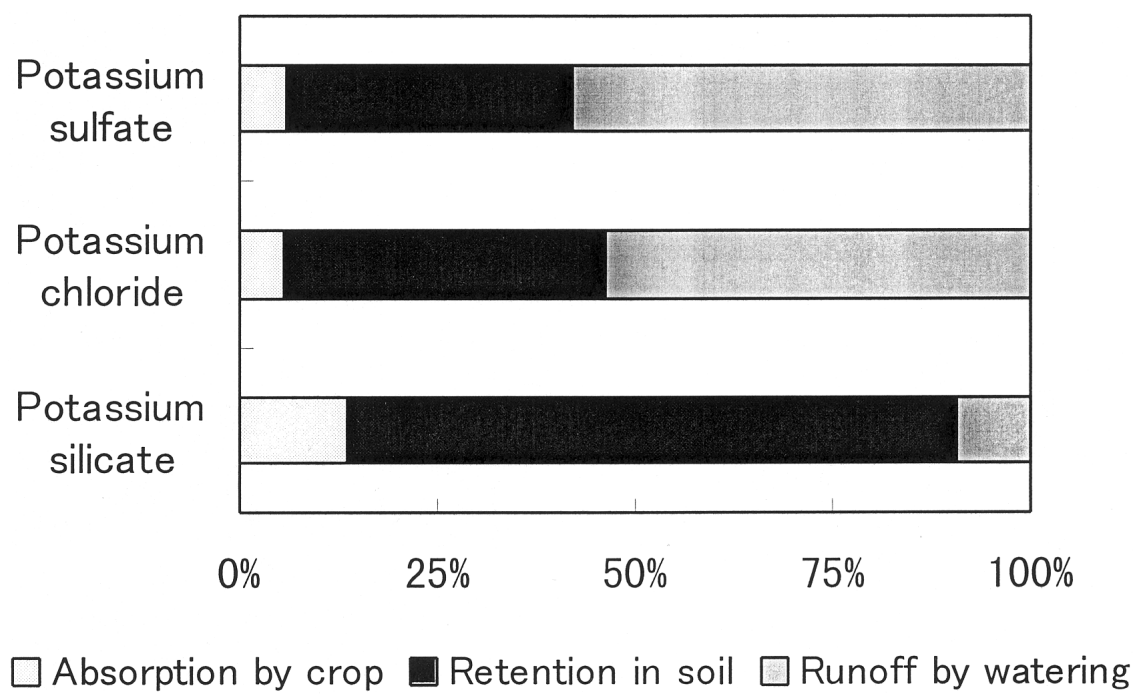

Fig. 5. Absorption and runoff in soil by type of potash compound.

resistance in rice, wheat and barley, this fosters an increase in the yield, and consequently the crop becomes resistant to abnormal weather conditions such as drought and cool summers. According to the report of International Fertilizer Development Center [20], worldwide consumption of fertilizer has increased from 33 million nutrient tons in 1962 to 143 million nutrient tons in 1996. Especially, consumption in Asia has shown a great increase from 2.5 million nutrient tons in 1963 to 54 million nutrient tons in 1996, that is, the present fertilizer market is over 21 times larger than in 1963. This transformation from coal ash into fertilizer has been commercialized at two plants producing 35000 and 20000 tons/year, respectively [21].

\section{Utilization of coal ash in desulfurization}

Acid rain is a serious global problem associated with air pollution, and the major contributors to acid rain are sulfur oxides ( $\mathrm{SO} x$ ) contained in emissions from such stationary sources as thermal power stations and industrial furnaces [22]. Many industrialized countries are now making efforts to reduce $\mathrm{SO} x$ emissions by installing equipment for flue gas desulfurization (FGD), and wet-type limestone scrubbing processes are widely employed because of their high DeSO $x$ efficiency and easy operation. However, these processes have drawbacks such as a large consumption of water and the need for wastewater treatment [23]. Dry-type FGD does not require wastewater treatment but needs a great amount of absorbent compared with wet-type FGD because a high molar ratio of calcium to sulfur is required for obtaining a high DeSO $x$ efficiency, and its by-product is calcium sulfite 
which has a considerable biological oxygen demand (BOD) when it is discarded [23]. Coal fly ash can be used as an absorbent for dry-type FGD. The method of manufacturing desulfurizing absorbent from coal fly ash is described as follows [24]: coal ash and slaked lime spent absorbent (mainly gypsum) stored in separate silos are weighed and then supplied to a powder-mixer. Almost the same amount of each material is mixed. The mixed material is then transferred to a kneader supplied with a sufficient amount of water. After kneading, this mixture is pelletized in an extruder and then steam-cured in a belt-type unit. During curing, a large pore volume (which is important for absorption with high efficiency) is obtained. The favorably large pore volume is considered to result from silicate and alumina dissolved from the coal fly ash and reacting with calcium to form a fine crystal complex. The obtained pellets are finally dried with hot air and stored in an absorbent silo. These absorbent pellets, in which calcium absorbs $\mathrm{SO}$ to fix it as gypsum, have a high reactivity with $\mathrm{SO}_{2}$ in the presence of $\mathrm{NO}, \mathrm{O}_{2}$ and $\mathrm{H}_{2} \mathrm{O}$ in flue gas. This is a dry-type process which generates no drainage and causes no drop in flue gas temperature, and so a gas heater is not required. NO especially plays an important role in $\mathrm{SO}_{2}$ absorption. Although the reaction scheme has not yet been clarified theoretically, it is supposed that $\mathrm{NO}$ is oxidized on the absorbent surface to form $\mathrm{NO}_{2}$, and then $\mathrm{NO}_{2}$ reacts with $\mathrm{SO}_{2}$ to form $\mathrm{NO}$ and $\mathrm{SO}_{3}$. Finally $\mathrm{CaSO}_{4}$ (gypsum) is obtained.

$$
\begin{aligned}
& \mathrm{NO}+1 / 2 \mathrm{O}_{2} \rightarrow \mathrm{NO}_{2} \\
& \mathrm{SO}_{2}+\mathrm{NO}_{2} \rightarrow \mathrm{SO}_{3}+\mathrm{NO} \\
& \mathrm{Ca}(\mathrm{OH})_{2}+\mathrm{SO}_{3} \rightarrow \mathrm{CaSO}_{4}+\mathrm{H}_{2} \mathrm{O}
\end{aligned}
$$

As shown in the above chemical formulas, the sulfur dioxides in the flue gas are fixed as gypsum. On the other hand, they are fixed as sulfite in other conventional dry processes such as limestone injection and active manganese. So some of the spent absorbent discharged from the desulfurization process can be used as the raw material for the absorbent pellets. In addition, this spent absorbent is reused as a solidification agent for sludge and as a deodorant for refrigerators, pet litter and so on [24]. The process flow is explained as follows: the system is composed of an absorber body, an absorbent feeder and a drawout facility, and an absorbent manufacturing facility. The absorbents in a fixed process are fed into an absorber and drawn out of its lower part. Both absorption and removal in sulfur dioxide are conducted during the time when the absorbents move down from the upper part to the lower part of the absorber. Flue gas containing sulfur dioxide is introduced to the absorber to make contact with the absorbents, and then the treated gas is discharged from a stack to the atmosphere [24]. A simplified plan view is shown in Fig. 6.

The FGD process using coal ash has been commercialized, and some industrial plants have achieved DeSO $x$ efficiencies of over $90 \%$, such as the Ebetsu power station $\left(50000 \mathrm{Nm}^{3} / \mathrm{h}\right)$ and the Tomtoh Atsuma power station $\left(644000 \mathrm{Nm}^{3} / \mathrm{h}\right)$ under a high molar ratio of calcium to sulfur (1.0-1.2) [24]. During operation, there is no need for wastewater treatment or gas reheating, and so this process is 
considered to be an ideal choice for controlling the emission of sulfur dioxide and an environmentally-friendly method for reuse of coal ash. Since the introduction of FGD in the late 1960s, global market demand for FGD has been steady at between 5000 and $10000 \mathrm{MW}$ per year, and mainly wet-type limestone FGD units have been installed [25]. As described in this part, wet limestone FGD requires a wastewater treatment facility. Furthermore, it emits carbon dioxide (greenhouse gas) into the atmosphere as follows:

$$
\mathrm{CaCO}_{3} \text { (slurry) }+\mathrm{SO}_{2}+1 / 2 \mathrm{O}_{2} \rightarrow \mathrm{CaSO}_{4} \text { (slurry) }+\mathrm{CO}_{2} \uparrow
$$

Dry-type FGD using fly ash is one of the processes that provide a solution to the above-mentioned problems, but this FGD has not yet spread worldwide.

\section{Discussion and conclusions}

Since the oil crises of 1973 and 1979, considerable effort has been put into the introduction and promotion of substitute energies for oil and as a result, the use of coal has been reconsidered and has increased worldwide. This involves the generation of a very large amount of fly ash, which will become a serious environmental problem, but the disposal of coal ash in landfills or coal mines is not strictly regulated by environmental law throughout the world. As a consequence, the low rate of coal ash recycling is of major importance nowadays, and attention has been focused on applications in the cement and construction industries. A great percentage (over 95\%) of the coal ash recycling rate has in fact been attributed to these industries (refer to Fig. 2). However, the economic recession in the building industry has greatly reduced the demand for coal ash [3], that is to say, there has been no expansion of applications of coal ash. Furthermore, the only significant

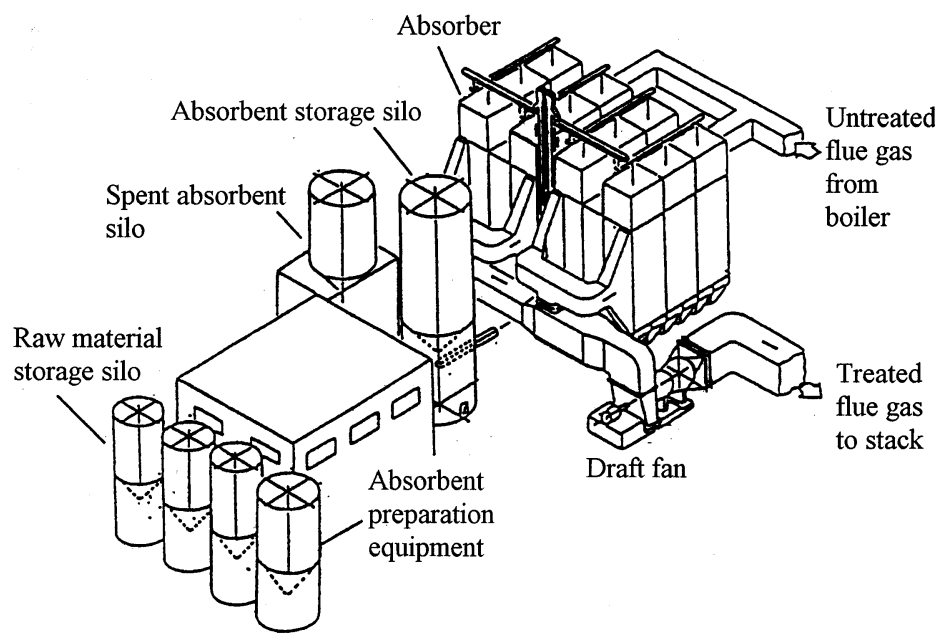

Fig. 6. Schematic plant view of flue gas desulfurization using coal ash. 
Table 4

Environmentally-friendly recycling of coal ash

\begin{tabular}{|c|c|c|}
\hline Recycling method & Usage & Marketability \\
\hline 1. Zeolitization & $\begin{array}{l}\text { Wastewater treatment, deodorant, } \\
\text { soil improvement }\end{array}$ & $\begin{array}{l}\text { Mineral deposits of natural } \\
\text { zeolite are localized. US\$ } \\
200-400 / \text { ton }\end{array}$ \\
\hline $\begin{array}{l}\text { 2. Transformation into } \\
\text { potassium silicate }\end{array}$ & $\begin{array}{l}\text { Agricultural fertilizer for rice, } \\
\text { fruits, vegetables, etc. }\end{array}$ & $\begin{array}{l}\text { Fertilizer demand has increased } \\
\text { especially in Asia }\end{array}$ \\
\hline $\begin{array}{l}\text { 3. Transformation into } \\
\text { desulfurizing agent }\end{array}$ & $\begin{array}{l}\mathrm{SO}_{2} \text { emission control (raw } \\
\text { material of FGD absorbent) }\end{array}$ & $\begin{array}{l}\text { The global FGD market is } \\
5000-10000 \mathrm{MW} / \text { year }\end{array}$ \\
\hline
\end{tabular}

user of coal ash (the construction industry) has been reducing its demand. Problems regarding the reuse of coal ash lie in its limited utilization, energy policy, and environmental regulations. Coal is distributed worldwide, and is a very stable and available energy source. It is expected that the demand for coal will increase with an increase in population and with economic growth, and so the amount of coal ash will become larger. Coal ash has a very narrow field of application. If coal ash disposal is strictly regulated by environmental law, the problem of what to do with the surplus ash will be aggravated and more difficult to solve. Expansion of the field of application of coal ash is a worthwhile subject of investigation, and applications should be environmentally-friendly to obviate secondary pollution. The three applications of coal ash presented in this paper may be summarized as shown in Table 4.

The conventional uses of coal ash have been mostly simple, for example, as a raw material for cement or a sub-base material. It is important for effective recycling to give a high added-value to coal ash. This will help to expand the field of application. As shown in Table 2, zeolite is used for wastewater treatment and in deodorant, and as a desulfurizing agent, is used for air purification. Both products have the function of environmental improvement. On the other hand, potassium silicate is used as an agricultural fertilizer, which seems unrelated to environmental improvement. However, agriculture is a factor of particular significance, being indispensable to human survival and also important in sustaining the stability of the global environment, and so application of coal ash to agricultural fertilizer can be considered to be a method of realizing the concept of sustainable development. An ecosystem consists of a recycling structure that has no environmental impact on nature. It should be emphasized that ideal waste treatment is nothing but environmentally-friendly recycling. The methods of recycling coal ash presented in this paper will be useful technically for realizing preferable means of recycling. However, the relation between the suppliers of coal ash and its users is a more important factor, that is, it is necessary to promote mutual understanding among the energy sector, zeolite consumers, FGD users, fertilizer producers, and farmers for realizing widespread implementation of the recycling methods presented here. Adoption of the described methods of recycling coal ash involves not only technical matters but also social and economical problems that must be solved. 


\section{Acknowledgements}

The author wishes to thank Dr Y. Pelovski (the Bulgarian Ministry of the Environment), Y. Naito (ZIA) and Y. Ishiwa (NSC) for providing unpublished data, $\operatorname{Dr}$ A. Mukherjee (University of Helsinki) for supporting bibliographical research, S. Umeda (CJC) and S. Nakanishi (EPDC) for procuring and forwarding relevant publications, Dr M. Lodenius (University of Helsinki) for offering data processing facilities, and C. Lentfer for English revision.

\section{References}

[1] OECD. http//www.iea.org/stats/file/selstats/cotpese.htm.

[2] Claus LB. Legislation for the Management of Coal-Use Residues. Technical report No. IEACR/68. London: IEA Coal Research, 1994:20-1.

[3] Ranta J. Amount, Quality of FGD Wastes in Finland. In: Kauppi P, Anttila P, Kenttamies K, editors. Acidification in Finland. Berlin: Springer-Verlag, 1990:1209-15.

[4] Blomster D, Leisio C. Fly Ash — Quality Recycling Material. In: Salminen P, Laiho Y, Kaikkonen H, editors. Energy Innovation 1996. Helsinki: IVO group, 1996:14-5.

[5] Walsh M. Kivihiili-ja Turvevoimalaitosten Sivutuotteet ja Niided Yottykaystto. Report No. $2,89$. Helsinki: Energiaalan Keskusliitto Energy, 1997 (in Finnish).

[6] Ando J. Flue Gas Cleaning Technology in the World. Tokyo: Japan Coal Technology Center, 1990:63-8.

[7] Nozaki F. Catalytic activities of coal ash and reformed coal ash in NO reducing reaction. Environmental Science 1982;B157-R32-3:33-5.

[8] Sudo T, Matusoka M. Crystallization of volcanic glass with alkaline solution. Mineralogy 1958;3:514-22.

[9] Iso F, Goto Y, Machinaga O. Simultaneous adsorption of ammonium and phosphate ions on the mixed adsorbents. Inorganic Materials 1995;2(255):100-7.

[10] Millier WC. Adsorption cuts $\mathrm{SO}_{2}$, NOx, Hg. Chemical Engineering 1973;6:62-4.

[11] Rosenburg HS. Purasiv N process. Operation Manual. Bandury: Union Carbide Co, 1975:15-25.

[12] Henmi T. A physico-chemical study of industrial solid wastes as renewable resource. Memorandum of the Faculty of Agriculture, Ehime University 1989;33(2):143-9.

[13] Okazaki M. Analytical Method for Soil Property. In: Yamane I, editor. Experimental Methods for Environmental Science. Tokyo: Hakuyu Publishing Co, 1993:213-7.

[14] The Powder Engineering Association. Grain and Powder Property Analysis. Tokyo: Nikkan Kogyo Publishing Co., 1975, p. 238-239.

[15] Grim RE. Applied Clay Mineralogy. New York: McGraw-Hill Publishing, 1962:318-20.

[16] Minato H. Mineral ores and mineral deposits of natural zeolites. Gypsum \& Lime 1991;235:531-46.

[17] Yorita G. Utilization of coal ash in power industry. Bulletin of the Electricity Association 1993;3:26-8.

[18] Kikuchi R. Transformation of air pollutants into the fertilizers (in Portuguese). Industria e Ambiente 1996;8:19-24.

[19] Aso S. Fertilizer. In: Tino M, editor. Plant Nutrition and Fertilizer. Tokyo: Asakura Publishing, 1995:162-206.

[20] Bumb, B.L. editor. Global and Regional Data on Fertilizer Production and Consumption, 1962-1996. Muscle Shoals: International Fertilizer Development Center (IFDC), 1998, p. 49-67.

[21] Company Profile of the Fertilizer Development Co. Ltd., Tokyo, 1990.

[22] Bull K., Fowler D., Urwin J, editors. Acid rain. Air quality Division. Bulletin of Department of the Environment of UK, London, 1991, p. 1-6. 
[23] Rochelle GT. Flue Gas Desulfurization. In: Edgar TF, editor. Coal Processing and Pollution Control. Houston: Gulf Publishing Co, 1983:337-55.

[24] Ngashima N, Arashi N, Kanda O. Operation results of the first commercial dry desulfurization plant in Hokkaido Electric Power Co. $\mathrm{SO}_{2}$ Control Symposium, 24-27 August 1993. Boston: Electric Research Institute, 1993. Volume 3, Sessions 7, 8A and 8B.

[25] Klingspor J, Tokerud A, Ahman S. Low coat FGD systems for emerging markets. ABB Review 1998;1(M-319):30-40. 